\title{
The Quality of Teaching Determines Students' Achievement in Writing
}

\author{
Deilis Ivonne Pacheco Sanz and Jesús-Nicasio García-Sánchez \\ University of Leon \\ Spain
}

\section{Introduction}

Recent research confirms that it is of great interest and relevance to analyze the level of agreement between the beliefs, attitudes, sense of self-efficacy, learning approaches and self-regulation of the teaching staff and students' achievement in written composition. In most cases, these studies present examples of the practical relationship between the teacher and the students' achievement in the instrumental areas linked to the teaching of writing, such as in the area of reading and mathematics. These studies are significant inasmuch as they have produced valuable information with respect to the levels of education, participants, instruments employed, interventions, teaching or rollout programs carried out, as well as information related to the priorities, organization and development of the research. These interesting contributions lead us to consider which aspects are evaluated within the classroom; the variables which are used to relate the teachers' practices to the students' achievements; the results obtained; the theoretical and educational implications, the limitations and deficiencies of the studies and suggestions for future research. (Álvarez et al., 2011; Díez et al., 2009; Pacheco et al., 2009; Pacheco et al., 2007).

In the process of revising within a Spanish and international cultural setting what promoted the interaction between teachers' practice and writing achievement, we found studies that claim that teachers' practices must be educationally consistent - integrating education and evaluation - in order to obtain positive effects in the activities, processes and results of the of students' learning (Flórez \& Monroy, 2008; Stokking et al., 2004).

Other studies have elaborated different categories explaining why the suggested practices are essential to students' success. Categories such as extra or additional classes and the use of active participation are examples of categories that help to improve student achievement. Both the authors claim promote the following activities: classes directed and dominated by discussion and work groups; discussions between teachers and students and, more importantly, among students; significant dialogues between students and teachers; active student participation during normal class sessions through questions and answers or discussing homework, break up groups, discussing together (teachers and students) the solutions to some problems, etc.; and, where categories and topics arise from the students, the teachers can provide answers (de la Fuente et al., 2008; Nkhoma, 2002). 
With this in mind, and in accordance with the new approaches regarding the teacherstudent relationship, different studies indicate that, at present, teachers may be able to make changes in the teacher-student continuum. This shift, will in turn lead students to behave more autonomously. The traditional type of interaction, which implies a strongly directive position for teachers, will cease to be effective in enhancing the progress or achievement of the students' autonomy. Additionally, this research emphasizes the terms teacher centered instruction - an authoritarian or traditional educational style which does not promote great transformations in the students - as opposed to student centered learning, where the education tends to be smooth, progressive and result in transformation (Valle et al., 2008; Flórez \& Monroy, 2008; Al-Weher, 2004; Taylor et al., 2002; Nkhoma, 2002).

Regarding the type of practices teachers carry out in the teaching of writing and how they influence academic achievement, some studies reveal specific strategies directed at teachers which have proven effective in creating a great variety of learning situations and effective instruction, in the case of students with and without difficulties of learning (LD) and/or underachievement (UP), so that these students develop their linguistic as well as their writing competence (Rosino, 2009; Fidalgo et al., 2008; Villalobos, 2007; García, 2007; García \& Rodriguez, 2007; García et al., 2006).

Teachers should be aware, through the studies that are currently available to them, of the key tools required for writing (processes, models, strategies, etc.), to be able to carry out the teaching of writing and thus help students acquire competence and fluidity at the lexical level, and progressively master the mechanisms of writing. Given that consolidating and becoming proficient in the orthographic system is a long process that demands a great deal of experience and practice, teachers must teach and encourage their students to self-regulate and control their word production. Thus, the common objective of teaching specific strategies is to assist students in becoming self-regulated learners, able to learn by themselves. One of these strategies, for example, is the revision process. Evidence shows that helping students increase the frequency and depth of their revision is a powerful strategy, allowing students the cognitive freedom to focus on the text and its correction (Rosino, 2009; Perez, 2001; Chanquoy, 2001).

In addition, many theories on writing promote the idea that writers' attitudes are formed or developed partly through the use of writing instruments and claim that technological instruments can make the writing process easier as well as increasing motivation for students with LD. These theories maintain that both students and teachers feel the effects of the new means of writing. In the case of the students, these new writing methods are favored, in terms of the quality of the product and the aspects of the students' achievement, which can describe their own behavior. Teachers also report students' greater desire to use these instruments, a greater motivation to begin new projects and to produce greater amounts of written work. The reasons for greater enjoyment include the presentation of high quality work, the speed at which the work can be produced and the ease with which a text can be organized and changed (Jiménez et al., 2003; Parr, 1994).

Other research has made interesting contributions to the principles that should be implemented both in order to prevent difficulties and to develop writing skills. Among these, we can emphasize the following : the provision of effective writing instruction; the preparation of instructions to detect each student's individual needs; early intervention to 
provide additional aid; the expectation that every student will learn to write; identifying and managing the academic barriers to writing; and, the use and development of technological instruments that improve writing execution. The most interesting point, according to the authors, is to look into how to reduce the children's difficulties in written composition and how the school and teachers can help these children with learning difficulties to improve their writing (Graham, 2006; Graham et al., 2001).

According to research, the writing education that many students receive is inadequate because it focuses almost exclusively on the teaching of lower level writing skills, such as calligraphy and spelling, with few opportunities to actually write. Other students are in classes with an increased frequency of writing tasks, but only a short amount of time is devoted to teaching the necessary writing skills and strategies, as it is assumed that these abilities can be acquired through informal and secondary methods of study. Other children attend schools where practically no time is devoted to ensure writing skills are obtained or to the teaching of writing. It is highly improbable that children with learning disabilities acquire the necessary knowledge in programs such as these (de Caso et al., 2011; Pacheco, 2010; García et al., 2009; Troia, 2006).

Most researchers believe the teaching of writing for these students should focus as much on prevention as on intervention; it should respond to the specific needs of each student; it should maintain a healthy balance between meaning, process, and form; and it should make as much use of formal methods of study as of informal methods. Designing instruction for the teacher as well as for the educational level is in itself not an easy task. However, it requires a coherent, coordinated, and extensive effort. The writing problems experienced by children with learning difficulties are not transitory difficulties that are eliminated easily, immediately or without establishing precise and effective practices (Graham, 2006; Troia, 2006; Villalobos, 2006; Graham et al., 2002; Graham et al., 2001). Based on the considerations addressed within this framework, in this research we propose, as a fundamental objective, to study written composition teaching practices in relation to the achievement of the students with and without LD and/or under achievement. Teachers' practice is thought to be based on their beliefs, attributions, expectations and the sense of personal efficacy that they hold with respect to the teaching-learning process. This is also closely related to students' achievements and the factors or components that modulate them (the students' motivation, the role that the parents or the family environment play in this process and the teacher's use of strategies, procedures and instruments in the area of writing or, in other curricular areas). Thus, the hypothesis supposes that the teachers' beliefs exert a strong influence on the practice of written composition and are predictive of students' success in the classroom. It is believed that this relationship varies depending on students' level of education and on the type of student.

\section{Methodology}

\section{Participants}

Participants were selected from two types of origin, although interrelated. One group was the sample of teachers taken from a previous study. The other groups were the students (of these teachers) who were classified into three categories - with attention deficit disorder (ADD), and without hyperactivity (ADHD), with or without learning disabilities (LD). 


\section{The teaching staff}

We evaluated 99 teachers from 30 private and state schools in the province of León, Spain, who teach Spanish language (the local first language) and are responsible for students with and without learning difficulties and/or low achievement, in the last year of infant education and the first three years of primary education.

The selection criterion for this sample was based on that used in previous studies the research team developed in these schools regarding different writing-related areas of interest - the influence of working memory and attention on students. The students addressed were both typically achieving and with learning difficulties, of different ages, with and without ADHD.

The teachers taught Spanish language to pupils in the second and third years of Primary Education, at 20 of the 30 private and state schools in the province of Leon, Spain. Of these teachers, $83.33 \%$ were women, $64.23 \%$ worked in state schools and $37.77 \%$ were employed by private schools. The average age of the teachers was 46.92 years, with a maximum age of 60 and a minimum of 27, which indicates both maturity and stability in the teaching career.

The average years of experience in this career was 23.43 years, which indicates significant educational experience. 18.84 of those years specifically devoted to language teaching. This means that they were experts in the instructional aspects related to teaching written composition. Only $12.4 \%$ had a bachelor's degree in philology or education and the remainder had a teaching degree in another specialist area. None of them had one in special education.

\section{The students}

The sample of students was selected in a similar fashion to the selection of the teachers. They were chosen following several strict criteria with the purpose of being able to match the sample with the needs and goals of this research project.

The first criterion was that the students selected receive classes from the teachers in the sample. This criterion was applied with the concurrent selection of the teachers, that is to say, the students and professors were selected simultaneously. The study was carried out independently by people different from those in the research Team on Excellence in PsychoEducational Intervention in Developmental and Learning Difficulties directed by second author. This was done as if they were independent studies; with the aim of ensuring there was no interference in the results. This ensured the teacher's knowledge of the research objectives did not interfere, and there would be no bias resulting from the knowledge of the true object of this study.

The second criterion was to include students from the three categories, that is to say, students with LD, students without LD and/or students with ADHD. The latter group was recruited from the Association of Parents of People with ADHD in the province of Leon (ALENHI, Leon Association of People with Attention Deficit Disorder with and without Hyperactivity). In addition, discrepancies between achievement and IQ of the students with writing LD were found in the intelligence measures, but that was not the case for students without LD or with ADHD, which was relevant to the selection of the samples. 
The third criterion required the sample to be representative of the spectrum of the educational levels for the teachers studied. The aim was to relate the achievement in written composition to the data collected from the sample of teachers. However, before the third year of Primary Education there is a limited production or level of written composition. This study addressed from the third year of Primary Education on. That is to say, we only included students of second (third and fourth years) and third cycle (fifth and sixth year) of Primary Education in the sample.

After applying the three criteria, a sample of 111 students of $3^{\text {rd }}$ to $6^{\text {th }}$ year of Primary Education was extracted (78 males and 33 females). Of these, 35 students had LD, 36 did not present LD and 40 had ADHD. Their ages ranged from 9 to 12 years. The average of age of the sample of the second cycle was 10 years old and the average of age of the third cycle was 11 years old. (For more details see Table 1 ).

\begin{tabular}{|c|c|c|c|c|}
\hline Student typology & Students & PE-2nd & PE-3rd & Total Level \\
\hline \multirow{5}{*}{ ADHD Students } & Male & 14 & 20 & 34 \\
\hline & Female & 3 & 3 & 6 \\
\hline & Total Level & 17 & 23 & 40 \\
\hline & Average age & 10 & 10.5 & \\
\hline & Min-Max & $9-11$ & $9-12$ & \\
\hline \multirow{5}{*}{ LD Students } & Male & & 20 & 19 \\
\hline & Female & & 16 & 16 \\
\hline & Total per Level & & 36 & 35 \\
\hline & Average age & & 11 & \\
\hline & Min-Max & & $10-12$ & \\
\hline \multirow{5}{*}{ Students without LD } & Male & & 25 & 25 \\
\hline & Female & & 11 & 11 \\
\hline & Total per Level & & 36 & 36 \\
\hline & Average age & & 10.5 & \\
\hline & Min-Max & & $10-11$ & \\
\hline Total Level & & 17 & 95 & 111 \\
\hline
\end{tabular}

Table 1. Distribution of the sample of students by type, gender, age and cycle of Primary Education.

\section{Instruments}

The instruments employed were concerned with measuring the teachers' variables, that is to say, with the role of practice in the teaching of the written composition, and with the measures of the students' variables. 


\section{Evaluation of the teaching staff}

The development of the instrument which is the object of this study began by first reviewing the Academic Search Elite databases, which are available at the Central Library of the University of León. Moreover, it was essential to study and review the legislation, educational programs and guides that establish the syllabi for both infant and primary education. This permitted the collection of information about the evaluation criteria in the area of Spanish language in each of the educational stages studied, and in particular the empirical data related to the focus of this research study.

These theoretical bases allowed the researchers to proceed to the collection, translation and, where appropriate, modification of the instruments used, as well as developing new tools to assess the areas and components that affect teachers' practice in the teaching of writing. Once created, they were subjected to validation (reliability, validity, norms, etc.) by the research team.

In this way, we obtained the instrument that evaluates the Role of Teachers Practice in Writing (PRAES), together with its corresponding questionnaires: the first focuses on opinion (PRAESPO), the second on the theoretical approach (PRAESPE) and the third refers to the classroom activity - what teachers actually do (PRAESPA) - and, finally, the focus of the last questionnaire was on self-efficiency (PRAESAE) (Pacheco et al., 2007).

\section{Overview of the psychological meanings assessed}

The PRAES is shaped both by the identity of the teacher, and by the four sections or questionnaires related to the components and factors that affect practice. (For details, see Table 2). The names of each questionnaire, presented in the order in which they are used in the PRAES protocol are as follows:

1. Practice-Opinion (PRAESPO), refers to the teachers' views regarding the role of the teacher in their teaching writing practice. It considers the following components and indicators: (i) The personal student component (motivation, planning and review), (ii) the practice component, (iii) the family component and (iv) teachers' training. This questionnaire was prepared by the research team.

2. The Practice Approach Questionnaire (PRAESPE) evaluates teachers' theoretical orientation in relation to the formal and the natural learning process of writing. This instrument was adapted from the Writing Orientation Scale (Graham et al., 2001).

3. The Classroom Practice Questionnaire (PRAESPA) measures the skills, instructional procedures, activities and materials used by teachers when teaching writing, and the type of text or the actual texts they use. This instrument was partially developed by the team and partly adapted and translated from Graham et al., (2001), based on his Teacher Writing Practices Scale.

4. The Teacher Writing Practices Scale Practice (PRAESAE) helps to better understand the type of factors that create both personal and general difficulties for teachers in their teaching, thus determining their self beliefs in the process of teaching writing. This instrument differentiates between self-efficacy and general efficacy. It was developed by the research team, based on the Teacher Efficacy Scale for Writing, adapted according to the directives and guidelines for constructing self-efficacy scales (Graham et al., 2001; Bandura, 2005). 


\begin{tabular}{|c|c|c|c|}
\hline Aspects Evaluated & Instrument & Tasks & Parameters \\
\hline The role of practice & PRAES & Four Questionnaires & Rating \\
\hline $\begin{array}{l}\text { Opinions about the factors that affect the } \\
\text { teaching of writing }\end{array}$ & PRAESPO & $\begin{array}{l}\text { Likert type } \\
\text { Questionnaire }\end{array}$ & Rating \\
\hline Theoretical Approach (natural vs. formal) & PRAESPE & $\begin{array}{l}\text { Likert type } \\
\text { Questionnaire }\end{array}$ & Rating \\
\hline Classroom Activities & PRAESPA & $\begin{array}{l}\text { Likert type } \\
\text { Questionnaire }\end{array}$ & Rating \\
\hline $\begin{array}{l}\text { Teachers' self-efficacy regarding the } \\
\text { teaching of writing (personal and } \\
\text { general) }\end{array}$ & PRAESPAE & $\begin{array}{l}\text { Likert type } \\
\text { Questionnaire }\end{array}$ & Rating \\
\hline
\end{tabular}

Table 2. Aspects evaluated in teachers and instruments used in research

\section{Student evaluation}

The instruments used to measure the student variables were of two types. Firstly, we used measures to monitor the level of students' general achievement and their level of intelligence and, secondly, instruments to measure specific achievement in written composition.

\section{General measures}

In order to measure intelligence, we used the Cattell assessment, with the purpose of selecting the suitable participants and, in particular, to establish the aptitude achievement discrepancy criterion (LD) or no discrepancy (under achievement), as well as to observe whether students had intellectual limitations (whether they had LD or ADHD or not). In addition, measures of general achievement were obtained through scale (from 1 to 4 ) and appreciation instruments filled out by the teachers regarding each of the students. For this type of instruments, several protocols were developed that covered all education levels (Infant Education, Primary Education, and Compulsory Secondary Education). These instruments were constructed specifically by the research team based on the guidelines of the Curricular Designs Base, the Ministerial Decrees and the Council of Education of the Region of Castile and Leon. They were elaborated through meticulous analysis, and were adapted to the objectives of the research team. This analysis was carried out with the goal of teachers evaluating the students' general achievement in language and mathematics.

The purpose of the application of these appreciation scales was to obtain an approximate measure. Although they were based on the teachers' opinion and therefore were subjective measurements, they do come from an expert on the student whom they teach. It fundamentally concerns the students' general achievement in language and mathematics, to be able to compare it with her/his level of intelligence, measured by the Cattell assessment, and to be able to state whether there is a discrepancy between aptitude or capacity and achievement (see Table 3). 
Students: General measures

\begin{tabular}{|c|c|c|c|}
\hline $\begin{array}{l}\text { Evaluated } \\
\text { Aspects }\end{array}$ & Instruments & Tasks & Parameters \\
\hline $\begin{array}{l}\text { Overall } \\
\text { Intelligence }\end{array}$ & IC Cattell & Four intelligence subtests & $\begin{array}{l}\text { Total score, CI total } \\
\text { and Centil }\end{array}$ \\
\hline \multirow[t]{2}{*}{$\begin{array}{l}\text { Overall Student } \\
\text { Performance }\end{array}$} & $\begin{array}{l}\text { Teacher Rating } \\
\text { Scales }\end{array}$ & $\begin{array}{l}\text { Questionnaire / Appreciative } \\
\text { Scale of performance in } \\
\text { language and math }\end{array}$ & $\begin{array}{l}\text { Ratings and } \\
\text { qualitative } \\
\text { observations }\end{array}$ \\
\hline & Students: Specific Me & easures & \\
\hline Writing Product & Editorial Writing & $\begin{array}{l}\text { Editorial writing and } \\
\text { comparison-contrast }\end{array}$ & $\begin{array}{l}\text { Objective and } \\
\text { subjective indicators }\end{array}$ \\
\hline $\begin{array}{l}\text { Text-based } \\
\text { Measures }\end{array}$ & Editorial Writing & $\begin{array}{l}\text { Editorial writing and } \\
\text { comparison-contrast }\end{array}$ & $\begin{array}{l}\text { Objective and } \\
\text { subjective indicators }\end{array}$ \\
\hline $\begin{array}{l}\text { Reader-based } \\
\text { Measures }\end{array}$ & Editorial Writing & $\begin{array}{l}\text { Editorial writing and } \\
\text { comparison-contrast }\end{array}$ & $\begin{array}{l}\text { Objective and } \\
\text { subjective indicators }\end{array}$ \\
\hline $\begin{array}{l}\text { Productivity and } \\
\text { consistency }\end{array}$ & $\begin{array}{l}\text { EPPyFPE (García, } \\
\text { Marbán, \& de Caso, } \\
\text { 2001) }\end{array}$ & Editorial writing & Indicators \\
\hline
\end{tabular}

Table 3. Aspects evaluated and instruments used in research on the students.

\section{Specific measures}

We measured specific achievement in written composition through two types of tasks. The first task entailed writing a free format text that served to establish the students' level of writing. It also helped establish whether there was a discrepancy between aptitude and achievement in writing, using the scales developed by the research team (García, 2001; García and Marbán, 2003). The scales corresponded with "the other measures of coherence" (relevance, connectors, paragraphs and argument thread) and, with several parameter measures (content and, functional words and determiners) that were previously applied by García and Marbán (2003). The measures of productivity and coherence were obtained from the written compositions of the participants in the planning tasks. Productivity is the amount of text developed by a student in each of the tasks. This productivity was verified by analyzing the words in the content, functional and determining words' parameters. A text is considered coherent when it presents information in an organized way, so that different receivers can perceive it as a unit. The coherence of the text was measured by means of relevance indicators to demonstrate theme continuity, and observe the ability to connect the ideas to construct proposals, to construct well-delimited paragraphs, to organize the sequence of these paragraphs to establish the thread of the argument throughout the text. When it was a narrative, the coherence analysis was carried out by means of a structure analysis, adjusted to include the indicators of a framework (time, space and characters) and of episode (initial event, response execution and consequence). In addition, for the tasks entailing converting matrices into propositions, the total scores of integration of the information were obtained (García and Marbán, 2003). 
The second task consisted of several texts of comparison-contrasts, where reader and textbased measures were taken. The parameters obtained from these tasks, were those that were used to relate the students' achievement in written composition to the role of the teachers' practices in the teaching of writing.

\section{Text-based measures}

The text-based measures evaluate information generation or productivity and the organization of the information, or the coherence and structuring of the information. For example, in the case of information generation, aspects such as the title, the number of paragraphs, the number of textual units, the number of verbs in personal form, the number of content words and, functional words and determiners are tallied. As for the organization of the information, objective elements relative to referential coherence (indicating referential and lexical coherence) and to the relational coherence (meta-structural and discursive indicators) were measured, as well as "other measures of coherence". As regards the aspects related to the structuring of the information, objective measures concerning the textual typology were used (comparison-contrasts) were measured as well as the number of punctuation marks (commas, periods, question marks, inverted commas, vignettes, etc.).

\section{Reader-based measures}

These concern a qualitative evaluation or judgment considering the specific criteria for the comparison-contrast type text. It involves making a global evaluation, as far as structure, coherence and quality are concerned, as indicated in detail in Table 4.

\begin{tabular}{|c|c|c|}
\hline $\begin{array}{l}\text { Type of } \\
\text { measures }\end{array}$ & $\begin{array}{l}\text { Evaluated } \\
\text { Appearance }\end{array}$ & Parameters \\
\hline \multirow{3}{*}{ Text Based } & Productivity & $\begin{array}{l}\text { Number of paragraphs } \\
\text { Number of sentences } \\
\text { Number of verbs } \\
\text { Number of words (determinants, content, functional, and } \\
\text { totals) }\end{array}$ \\
\hline & Consistency & $\begin{array}{l}\text { Number of cohesive ties: anaphoric, lexical, meta, } \\
\text { structural, connective, argumentative, reformulative } \\
\text { Referential consistency: anaphoric and lexical ties } \\
\text { Relational consistency: metastructural, connective, } \\
\text { argumentative and reformulative ties } \\
\text { Total consistency: relational and referential coherence } \\
\text { Density of consistency: number of ties for every } 100 \text { words }\end{array}$ \\
\hline & Structure & $\begin{array}{l}\text { Number of main parts of a text, introduction, main body } \\
\text { and conclusion }\end{array}$ \\
\hline \multirow{3}{*}{ Reader based } & Structure & Rating (1-4) \\
\hline & Consistency & Rating (1-4) \\
\hline & Quality & Rating (1-6) \\
\hline
\end{tabular}

Table 4. Aspects used to evaluate the text produced (translated Garcia \& Fidalgo, 2006, pp. 185) 


\section{Procedure}

The study presented here, which is a descriptive study, consisted of two comparative and related samples, chosen simultaneously from 30 schools. The samples were selected to complement each other. In fact, the research team was carrying out a series of studies in the province of León which required samples of students from three different categories which are matched for general characteristics: a group of students with LD, another group without LD and a group of students with ADHD.

The sample of the teachers was selected on the basis of the criterion explained above. They were teachers who were responsible for students with and without learning difficulties and/or low achievement in infant and early primary education. The next step was the fieldwork itself. It consisted, firstly, of establishing telephone contact with the school principals to obtain permission to visit and carry out the protocol with the language teachers of the selected school years in each of these schools. Two researchers then visited the schools on the agreed dates and times and asked teachers to complete the protocols. The sample selection was performed directly by the two researchers and not by other means, to ensure the reliability and validity of the instruments in the collection of information. Data collection was conducted over a period of five months.

The procedure followed for the data collection from students can be summarized in the following steps. Firstly, general measures of sample selection were applied. Different members of the research team, with an approximate duration of 10 to 20 minutes, carried out an IQ measurement using the Cattell assessment in small groups. After the Cattell assessment, students were asked to carry out different written composition tasks. Small groups of students carried out individual free text exercises (García, Marbán, and de Caso, 2001), to determine their level of achievement in writing. Several comparison-contrast texts were written to obtain the indicators and the measures of the product of the writing (text and reader-based measures). These measures were used to relate the students' achievement in writing to the role of the teachers' practice, which constitutes the object of this study. Our basis for this sample came from an initial sample of more than 350 students from previous studies carried out by the research team, of which only 111 students were selected for this study. Simultaneously, the teachers were asked to complete evaluation scales regarding the each student's general achievement. This task took some time and once finished the forms were collected.

Along with the application of these instruments and tasks, a further set of tests and questionnaires were applied. These were related to attention, working memory, and the study of the online processes used in written composition. They were measured by means of a writing log, but they are not included in this study, as they are part of an overarching project including different studies with broader goals than those presented in this article. Once all the assessments were carried out in the 30 schools, the members of the research team analyzed all the texts. Members of the team, who had received specific training over several meetings, including the study of the correction dossier and the systematic supervision of the written texts, carried out their meticulous correction. The texts were corrected twice and anonymously with the purpose of reaching an agreement between coders. The approximate time dedicated to the correction of texts for each student was of two hours, including the codification and computerization of the data. The correction was 
carried out after eliminating the data concerning the students' identity, their typology, age, school, and gender, etc. Therefore, the evaluators were blind to the origin, level, etc. of students. In addition, corrections were systematically balanced to ensure that all the correctors marked texts belonging the three student categories and from all participants levels of education. The data from the corrections of the general measures and of the specific measures of the written composition, along with the data provided by teachers, were codified and computerized in Excel matrices by the team members. These Excel matrices were then integrated into a single SPSS matrix by the research director who also carried out the different statistical analyses (univariate and multivariate analysis) and the interpretation of the results.

\section{Results}

After the creation of a single matrix on SPSS (v. 13.0) with the variables generated for the data regarding teachers and students, the following types of analysis were carried out: multivariate analyses of variance (MANOVAS) using the SPSS Model Lineal General module (MLG) and multiple linear regression analyses (ARL).

\section{General Linear model}

The multivariate contrasts in the student based measures based on their typology (ADHD, LD versus without $L D)$, indicate highly significant statistically results with a large size effect $\left[\mathrm{F}(84,28)=3.52 ; \mathrm{p}=.001 ; \eta^{2}=.914\right]$.

For the execution of these multivariate analyses of the three student typologies (ADHD, with and without LD) and, as dependent variables, the different measures obtained for the students and the teachers were taken as intersubject factors. The purpose of this was to highlight the differences between the teachers as regards the role of practice in the teaching of writing. We also sought to show the differences according to student typology and to try to extract some pattern to help understand the relationship between the teachers' writing teaching practice and the students' achievement.

The tests concerning the intersubject/intergroup effects also indicated statistically significant results in most of the dependent variables related to students and to teachers. The size effects, in general, were large. When the grouping variable (intersubject factor or fixed factor) belonging to a specific group was taken (with ADHD, with and without LD), statistically significant differences were observed, both in the writing tasks and in comparison-contrast texts. In the comparison-contrast texts significant differences were observed for the variables of information generation, organization of ideas, structure, reader-based quality measures, etc. For example, for organization of ideas in relational coherence $\left(\mathrm{p}=.001 ; \mathrm{\eta}^{2}=.217\right)$; or for reader-based measurement as concerns structure $(\mathrm{p}=$ $\left..001 ; \eta^{2}=.213\right)$; and for reader-based evaluation (order-quality) $\left(p=.001 ; \eta^{2}=.284\right)$. Also, in the writing task, statistically significant differences were observed for idea generation and total productivity $\left(\mathrm{p}=.001 ; \mathrm{\eta}^{2}=.268\right)$; in the reader based evaluation (order and structure) $\left(\mathrm{p}=.001 ; \mathrm{y}^{2}=.486\right) ;$ and in quality $\left(\mathrm{p}=.001 ; \mathrm{\eta}^{2}=.383\right)$.

As concerns what teachers actually did (see Table 5), it was interesting to observe that it differed according to the students taught, in motivation (close to statistical significance), in natural teaching approach, and in self-efficacy (very close to statistical significance). The tests of the intersubject effects indicated statistical significance for the opinion variables, 
motivation subcomponent $\left(\mathrm{p}=.073 ; \mathrm{\eta}^{2}=, 091\right)$; approach, natural learning subcomponent $(\mathrm{p}=$ $\left..002 ; \eta^{2}=, 205\right)$; and, close to statistical significance for general self-efficacy $\left(p=.058 ; \eta^{2}=, 098\right)$.

\begin{tabular}{llllllllll}
\hline Measure/group & \multicolumn{7}{l}{ ADHD $(\mathrm{N}=40)$} & $\mathrm{DA}(\mathrm{N}=35)$ & $\mathrm{SDA}(\mathrm{N}=36)$ \\
\hline Variables & $\mathrm{M}$ & $\mathrm{a}$ & $\mathrm{M}$ & $\mathrm{A}$ & $\mathrm{M}$ & $\mathrm{a}$ & $\mathrm{F}$ & $\mathrm{p}$ & $\mathrm{n}^{2}$ \\
Opinion: Reasons & 29.59 & 3.84 & 28.18 & 4.96 & 31.32 & 3.72 & 2.74 .073 .091 \\
Opinion: Planning and revision & 24.12 & 2.08 & 24.91 & 2.22 & 26.16 & 1.97 & 1.18 .314 .041 \\
Opinion: Practice & 30.59 & 4.34 & 31.64 & 3.23 & 33.00 & 2.47 & 2.30 .109 .077 \\
Opinion: Family & 15.41 & 2.47 & 14.09 & 2.91 & 15.26 & 1.55 & 1.83 .170 .062 \\
Formal Education Approach & 39.88 & 8.08 & 37.64 & 7.65 & 41.21 & 6.90 & 1.18 .315 .041 \\
Natural Learning Approach & 34.59 & 7.06 & 27.91 & 4.63 & 30.26 & 4.86 & 7.08 .002 .205 \\
Classroom: Skills & 24.29 & 3.72 & 23.05 & 3.33 & 22.95 & 2.97 & .907 .410 .032 \\
\hline General Self-efficacy & 33.05 & 10.06 & 38.31 & 4.79 & 37.00 & 4.92 & 3.00 .058 .098 \\
\hline
\end{tabular}

Table 5. Statistically significant results: multivariate analysis of variance in the teachers' measures (PRAES) between groups of students with ADHD, DA and without DA

When the contrasts between the significant variables obtained in the tests of the intersubject effects (between the groups) were collated post hoc, we found statistically significant differences in many of them (see Table 6). For example, there were significant differences among the post contrasts and between the group with LD and the group without LD. The same was noted for the ADHD group, that showed significant differences compared to the group without LD. However, no significant differences were noted between the groups of students with LD and those with ADHD. This pattern was observed in the variables that refer to the writing task in total productivity (LD as opposed to without LD, $\mathrm{p}=.001$; without LD as opposed to ADHD, $p=, 047$ ) and for organization of ideas, referential coherence (with as opposed to without LD, $\mathrm{p}=, 051$ ). Other patterns noted are also of interest, for example, the significant differences between the three groups, as is the case with the reader-based structure measures (with LD as opposed to without LD, $\mathrm{p}=.001$; LD compared with ADHD, $\mathrm{p}=.056$; and without LD compared with ADHD, $\mathrm{p}=, 001$ ).

Also, we would also like to highlight the results concerning the teachers - the statistical significance related to the motivation variable $(p=.073)$, natural teaching approach $(p=.002)$ and general self-efficacy $(\mathrm{p}=.058)$.

The post hoc contrasts indicated different patterns between the students with and without $\mathrm{LD}$ and ADHD with regard to the teacher related variables. There were likewise differences between the group with LD and those without LD. The ADHD group is significantly different from the group without LD, but this is not so between the LD and ADHD groups. This pattern is observed in the natural teaching approach variable (LD as opposed to ADHD, $\mathrm{p}=.002$; and without LD as opposed to ADHD, $\mathrm{p}=, 072$ ). The non-significant variables related to the PRAES include those which correspond to: Opinion and the subcomponents of practice $(p=.109)$, family $(p=.170)$ and teacher training $(p=.650)$; the formal approach $(\mathrm{p}=.315)$; the actual classroom behaviors and the subcomponents of abilities $(\mathrm{p}=.410)$, materials $(\mathrm{p}=.874)$, procedures $(\mathrm{p}=.271)$, texts $(\mathrm{p}=.278)$ activities $(\mathrm{p}=$. $454)$; and personal self-efficacy $(p=.913)$. These variables, to some extent, predict teachers' behaviors in the teaching of written composition (see Figure 1). 


\begin{tabular}{|c|c|c|c|}
\hline & \multicolumn{3}{|l|}{$\operatorname{Essay}(p)$} \\
\hline Variable & LD vs. WLD & LD vs. ADHD & WLD vs. ADHD \\
\hline Total Productivity & .001 & n. s. & .047 \\
\hline Organization of ideas: consistency referential & .051 & n. s. & n. s. \\
\hline Organization of ideas: total coherence & .049 & n. s. & n. s. \\
\hline Other aspects: overall coherence & .041 & n. s. & n. s. \\
\hline Reader based evaluation: amount, structure & .001 & .056 & .001 \\
\hline Reader based evaluation: summary, consistent & .001 & n. s. & .001 \\
\hline Reader based evaluation: amount, quality & .001 & n. s. & .002 \\
\hline Reader based evaluation: order, structure & .001 & n. s. & .001 \\
\hline Reader based evaluation: order, coherence & .001 & n. s. & .001 \\
\hline \multirow[t]{2}{*}{ Reader based evaluation: order, quality } & .001 & n. s. & .001 \\
\hline & \multicolumn{3}{|c|}{ Comparison-contrast $(p)$} \\
\hline Productivity total & n. s. & n. s. & .075 \\
\hline Relational Consistency & .029 & n. s. & .002 \\
\hline Total Consistency & n. s. & n. s. & .052 \\
\hline Other aspects: overall coherence & n. s. & .039 & .001 \\
\hline Reader based evaluation: amount, structure & .005 & n. s. & .055 \\
\hline Reader based evaluation, summary: consistent & .005 & n. s. & .001 \\
\hline Reader based evaluation, amount: quality & .003 & n. s. & .002 \\
\hline Reader based evaluation, order: structure & .008 & n. s. & .005 \\
\hline Reader based evaluation, order: coherence & n. s. & n. s. & .027 \\
\hline Reader based evaluation, amount: quality & .001 & n. s. & .001 \\
\hline
\end{tabular}

Table 6. Post-hoc significant contrasts in the multivariate analyses, both for the students' writing tasks (by type) and for the teachers' actions (by type of students)

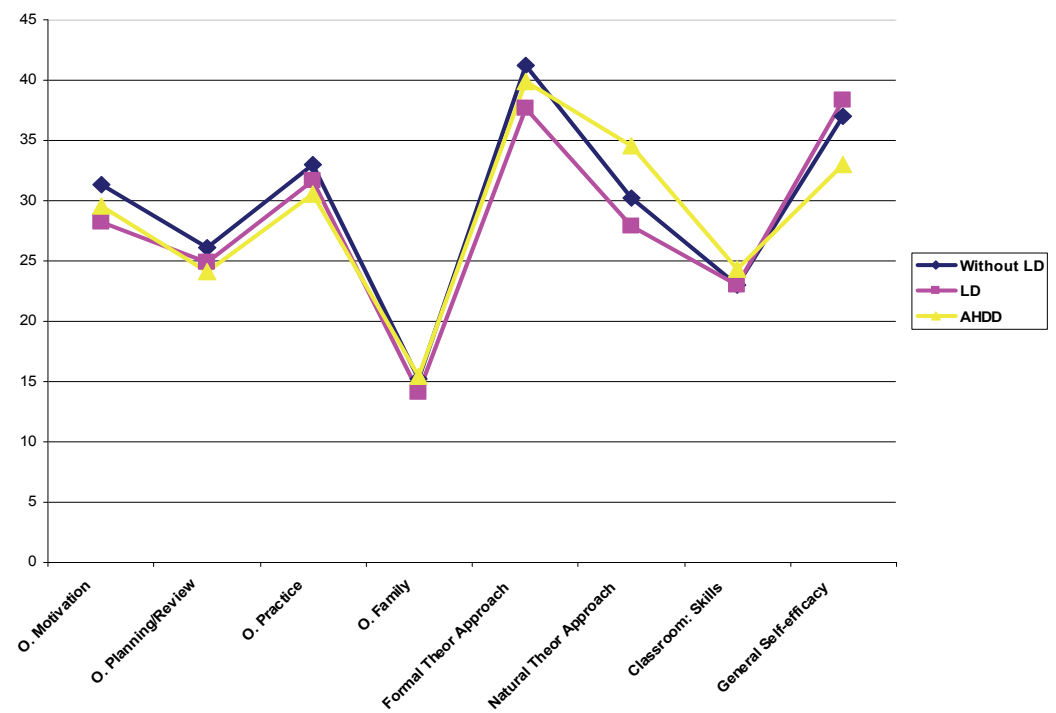

Fig. 1. Statistically significant differences in the teachers' variables, depending on student typology. 


\subsection{Multiple linear regression analysis}

\section{Prediction of student typology}

If we considering the total writing measures (product totals from reader and text-based measures) and the measures of the PRAES (scale and the subscale totals) as predicting variables, and the type of student as the predicted variable, we obtain statistically significant results. When the measures are taken only from writing, statistically significant results in the prediction of the type of students were also obtained. However, when only the PRAES results are considered, they do produce statistically significant results in the prediction of the type of student. In any case, this is interesting, as it does not support the idea of there existing differences in the teachers' practices based on student typology. When the type of student is taken as a dependent variable (ADHD, LD, without LD) or as a variable predicted by the set of the total measures of the written product (students' achievement), in the hierarchic multiple regression step-by-step analysis, we obtained one model with a statistically significant regression coefficient $\left(\mathrm{R}^{2}\right.$ corrected $\left.=.496\right)$. The variables in the model that reached statistical significance are, among others: writing, reader based evaluation concerning order and structure $[\beta=.711 ; \mathrm{t}=7.557 ; \mathrm{p}=.001]$ and other aspects of total coherence $[\beta=-.283 ; \mathrm{t}=-2.447 ; \mathrm{p}=.018]$; those from the PRAES as regards classroom practice and the procedure subcomponent $[\beta=-.237 ; \mathrm{t}=-2.645 ; \mathrm{p}=.011]$ and for the opinion and the motivation subcomponent $[\beta=.182 ; \mathrm{t}=2.167 ; \mathrm{p}=.035]$. The remaining variables were excluded from the model, as they did not reach statistical significance.

\section{Prediction of the written product}

When the writing variables (the product totals from the reader and text-based measures) are taken as predicted variables and the PRAES variables as predicting, many produce statistically significant results, albeit of a low level. However, this is interesting, as they indicate a tendency, and given the nature of the different measures this points towards results which are very relevant from a theoretical point of view.

The fact that some total measures from the PRAES predict some totals for the writing product is very interesting, given that there is some relationship between the two. For example, the factors that are involved in the prediction of total productivity include the factors attributed to the family and the formal teaching approach, as are those used by teachers who will mainly employ these in students without LD. Other variables regarding teaching staff that predict some measure of achievement in writing are the procedures used (in several variables), the role assigned to the family, the materials used (in several variables), the natural teaching approach (more used with the group of students without LD and those with ADHD), personal self-efficacy, the formal teaching approach, teacher training, motivation, classroom practices, the use of plans and revision.

Of the 27 regression analyses extracted to predict writing based on PRAES, 23 were found to have statistical significance. The variables from the PRAES that are predictive regarding writing concentrate on the family subcomponent, classroom activities with the subcomponents of procedures and materials, in addition to the formal theoretical approach, the natural learning approach, personal self-efficacy, teacher training, motivation and the aspects of planning and revision. In addition, the attempt to predict writing achievement based on total productivity and the number of words parameter from the PRAES was 
carried out and a corrected $\mathrm{R}^{2}$ of .067 was obtained. This is significant, although it only generates a regression model or equation with the predicting variables of PRAES for opinion with the family subcomponent $[\beta=.276 ; \mathrm{t}=2.817 ; \mathrm{p}=.006]$ and for approach, with the subcomponent of formal approach $[\beta=.217 ; \mathrm{t}=2.213 ; \mathrm{p}=.029]$. It does not generate any other significant variables, which we have therefore excluded from the model.

In summary, regression analysis provides statistically significant data for predicting all the writing variables within PRAES, which presents interesting data regarding predictive validity. It also indicates the great predictive potential of the instruments applied, as they allow us to observe variables that are not always of the same nature.

\section{Discussion and conclusions}

The objective of the present study was to consider the teachers' self-regulation in the teaching of written composition in relation to the achievement of students with and without LD and/or under achievement. It was expected that the results of this study would show that the teachers' beliefs both affect and have a strong influence in their classroom practices concerning written composition and also that this predicts students' success. According to the results obtained it is possible to affirm that, broadly speaking, the objective was achieved. As for the hypotheses, they were only proven for some measures but not for others. For example, data was obtained which supports the differences between the students based on the PRAES assessment. The potential of the PRAES to predict writing achievement was also demonstrated. However, data was collected which does not necessarily corroborate the prediction of the typology of students based the PRAES. This may be due to the nature of the measures or perhaps because there is no actual predictive potential. As far as the sample is concerned, as well as being representative, relevant and of a broad spectrum (compared with the samples in other empirical studies), it also allows us to describe the students' achievement according to the type of practice employed by teachers.

As regards the instruments used, given the revision of empirical and theoretical studies published in recent years, we can confirm that the PRAES and the applied writing measures (general and specific) used to evaluate both general achievement and specific aspects of written composition display not only acceptable validity and reliability but, also, appropriate sensitivity to the detection of differences based on the type of student and according to the prediction between variables. It is important to highlight that we know of no published studies that jointly employ the four PRAES components (Opinion, Approach, Classroom Behavior, Self-efficacy) to evaluate teachers, as well as the instruments applied to evaluate and to measure students' general and specific achievement in written composition, and that link both teacher and student measures. This justifies and affords relevance to the present study. As concerns the statistical analysis and its contribution to the study, when taking the intersubject factors - the three typologies of students (ADHD, LD, without LD) as dependent variables, the different measures obtained for students and teachers verify the differences among the teachers regarding the role of their practice in teaching written composition, based on the differences according to the students' typology.

The results obtained are of high statistical significance in most of the dependent variables regarding students and teachers, with large effect sizes, in general. As regards the students, when belonging to one group type is taken as a grouping variable (with ADHD, with and 
without LD), statistically significant differences are observed, both for the writing tasks as for the comparison-contrast texts. In comparison-contrast texts, significant differences were observed regarding the variables of information generation, organization of ideas, structure or reader-based quality. Examples include the organization of ideas in relational coherence, reader-based evaluation concerning structure, and reader-based evaluation for order and quality. Also, in the writing task statistically significant differences were found regarding idea generation and total productivity, in reader-based evaluation for order, structure and quality. As far as teachers are concerned, it is interesting to observe that they behave differently based on the students they have, as regards motivation, general or natural teaching approach and self-efficacy. The tests of intersubject effects indicated statistical significance for the opinion variables, in the subcomponents of motivation; approach, natural learning; and general self-efficacy.

When trying to extract some pattern that would help understand the relationship between what teachers actually do when they teach writing and students' achievement, a very interesting observation was made. A relationship was noted underlining the fact that some total measures of the PRAES predicted some totals of the writing product. Other variables concerning the teachers that helped to predict some measures in writing achievement were the procedures used, the role assigned to the family, the materials employed, the natural teaching approach, personal self-efficacy, the formal approach, teacher training, motivation, the practice and the use of plans and revisions. Of these, those that most significantly predict writing variables are: the family, the activities carried out in the classroom along with the procedures and the materials used, as well as the use the formal theoretical approach.

When the type of students (ADHD, with and without LD) was taken as an independent or a predicted variable from the set of total measures of the writing product we found variables included in the model related to writing: writing a draft, reader-based evaluation, order and structure and other aspects of total coherence. We also noted variables related to the PRAES: practice in the classroom in the procedure subcomponent; opinion and the motivation subcomponent. The remaining variables were excluded from the model, as they did not reach statistical significance. When we attempted to predict writing achievement through total productivity in the 'number of words' parameter, a regression model or equation was obtained with the following PRAES predicting variables: opinion, the family subcomponent, and the formal approach. No other variable was found to be significant. These factors are, at least indirectly, based on the type of teachers' practice in the area of Spanish language. There were no significant differences in relation to the theoretical concepts and strategies applied in the teaching of writing in the different school years from Infant to Primary. There were, nevertheless, differences based on age, which is an indicator of some type of adjustment according to the students' stage of development. According to the results obtained, all teachers seem to act in a homogenous way as far as the theoretical conceptions that direct their behavior are concerned - or in other respects, which indicates poor selfregulation of their practice. In addition, it appears that their practice of teaching writing does not substantially differ between students with and without learning difficulties and/or low levels of achievement.

It is clear that this study presents evident limitations concerning the use of PRAES, and it should be complemented with direct observation of the teachers' behavior as well as direct 
observation of students' achievement in the classroom. It also seems reasonable to carry out this type of analysis in other areas and to observe whether there is any general pattern or specific patterns related to the practices in each area.

\section{Acknowledgments}

During this research study, we received competitive funds from the Spanish Ministry of Education, Science and Innovation (MICINN) (EDU2010-19250 / EDUC) for 2010-2013, and Excellence Research Group funds from the Junta de Castilla y León (GR259), with FEDER funds from the European Union for 2009-2010-2011 (BOCyL 27 on April 2009). Both were awarded to the Director/Main Researcher (J. N. García). We are very grateful to Victoria Rosa Sturley for her help with the English version.

Correspondence should be addressed to Departamento de Psicología, Sociología y Filosofía. Área Psicología Evolutiva y de la Educación. Campus de Vegazana s/n, 24071 - León, Spain. Phone: +34-987291041 (university); +34-987222118 (home); +34-652817871 (cell); Fax: +34-987291035 (university). E-mail: jn.garcia@unileon.es.

\section{References}

Almargot, D. \& Chanquoy, L. (2001). Through the models of writing. Kluwer Academic Publishers (Ed.), ISBN 7923-6980-7, Dordrecht, The Netherlands.

Álvarez, M.; Robledo, P.; García, J.; de Caso, A.; Pacheco, D. \& García-Martín, J. (2011). Metodologías trabajadas y favorecedoras del aprendizaje [Tried methodologies that enhance learning], Educación, aprendizaje y desarrollo en una sociedad multicultural. Psicología de la instrucción, pp. 7379-7386, [Education, learning and development in a multicultural society. Psycology of Instruction], In J.M. Román Sánchez, M.Á. Carbonero Martín and J.D. Valdivieso Pastor (Comp.), Asociación Nacional de Psicología y Educación, (Ed.), ISBN 978-84-614-8296-2, Valladolid, Spain.

Al-Weher, M. (2004). The effect of a training course based on constructivism on student teacher's perceptions of the teaching/learning process. Asia- Pacific Journal of Teacher Education, Vol. 32 No.2, pp. 169-184, ISSN 1359-866X.

Chanquoy, L. (2001). How to make it easier for children to revise their writing: A study of text revision from 3rd to 5th grades. British Journal of Educational Psychology, Vol. 71, pp. 15-41, ISSN 0144-6657.

De Caso, A.; García, J.; Pacheco, D.; Robledo, P.; Álvarez, M. \& García-Martín, J. (2011). Componente motivacional, estrategias de aprendizaje e innovación educativa [Motivational component, learning strategies and educational innovation], Educación, aprendizaje y desarrollo en una sociedad multicultural. Psicología de la instrucción [Education, learning and development in a multicultural society. Psycology of Instruction], (pp. 7343 -7353), In J. M Román Sánchez, M. Á. Carbonero Martín and J. D. Valdivieso Pastor (Comp.). Asociación Nacional de Psicología y Educación, (Ed.), ISBN 978-84-614-8296-2, Valladolid, Spain.

De la Fuente, J.; Pichardo M.; Justicia, F. \& Berbén A. (2008). Enfoques de aprendizaje, autorregulación y rendimiento en tres universidades europeas. [Approaches to learning, self-regulation and performance in three European universities]. Psicothema, Vol. 20, No. 4, pp. 705-711, ISSN 1132-9483. 
Díez, M.; García, J.; Robledo, P. \& Pacheco, D. (2009). Habilidades sociales y composición escrita en alumnos con dificultades de aprendizaje y/o bajo rendimiento. [Social skills and written composition in students with learning disabilities and/or low performance]. Boletín de Psicología [Psychology Bulletin], No. 95, pp. 73-86, ISSN O212-8179.

Fidalgo, R.; Torrance, M. \& García, J. (2008). The long term effects of strategy-focused writing instruction for grade six students. Contemporary Educational Psychology, Vol. 33, pp. 672-693. ISSN 0361-476X.

Flórez, A. \& Monroy, E. (2008). Autorregulación pedagógica a través de estrategias. Alternativas de evaluación en la universidad. [Educational self-regulation strategies. Alternative assessments in university]. Foro regional de evaluación del aprendizaje en la educación superior [Regional forum for the evaluation of learning in higher education]. Ministerio de Educación Nacional. Universidad de la Amazonía.

García, J.; de Caso, A.; Fidalgo, R.; Arias, O.; Pacheco, D. \& Torrance, M. (2009). Investigaciones recientes en desarrollo e instrucción en composición escrita en el Sistema Educativo Español. [Recent research in development and instruction in written composition in the Spanish Educational System]. Aula Abierta [Open learning], Vol. 37, No. 1, pp. 91-104, ISSN 0210-2773.

García, J. (2007). Introducción y justificación del libro dificultades del desarrollo y del CDRom instrumentos y programas de intervención. Dificultades del desarrollo: Evaluación e intervención [Developmental Challenges: Assessment and Intervention], In J. N. García (Coord.), pp. 23-28, cap. 1, Pirámide (Ed.), ISBN 978-84-368-2008-0. Madrid, Spain.

García, J. (2001). Dificultades de aprendizaje e intervención psicopedagógica. [Learning difficulties and intervention counseling], Ariel (Ed.), ISBN 9788434426412, Barcelona, Spain.

García, J. \& Fidalgo, R. (2006). Effects of two types of self-regulatory instructions in students with learning disabilities in writing product, process and self-efficacy. Learning Disability Quarterly, Vol. 29, No. 3, pp. 181-211, ISSN 0731-9487.

García, J. \& Marbán J. (2003). El proceso de composición escrita en alumnos con DA y/o BR: Estudio instruccional con énfasis en la planificación. [The process of writing in students with LD and/or BR: A study with emphasis on instructional planning] Infancia y Aprendizaje [Childhood and Learning], Vol. 25, No. 4, pp. 1-18, ISSN 02103702.

García, J.; Pacheco. D.; Díez, C.; Robledo, P.; Mtnez-Cocó, B.; Rodríguez, C.; González, L., de Caso, A.; Fidalgo, R. \& Arias-Gundín, O. (2006, October). The role of the teacher's practice in writing related with writing product and process in students with and without LD. 15th Congress on Learning Disabilities Worldwide. 26, 27, 28 Oct., Boston, Burlington: LDW.

García, J. \& Rodríguez, C. (2007). Influence of the interval recording and graphic organizer in the process and product of writing and other psychological variables. Psicothema, Vol. 19, No. 2, pp. 198-205, ISSN 1132-9483.

García, J.; Rodríguez, C.; Pacheco, D. \& Díez, C. (2009). Influence of cognitive effort, sustained attention, working memory and ADHD symptoms in the process and product of written composition. An experimental study. Estudios de Psicología, Vol. 30, No. 1, pp. 31-50, ISSN 0210-9395. 
Graham, S. (2006). Strategy instruction and the teaching of writing. A meta-analysis. In: Handbook of Writing Research, Charles A. MacArthur, Steve Graham, Jill Fitzgerald, (Ed.), pp. 187-207, The Guilford Press, ISBN 1-59385-190-1, New York, United States of America.

Graham, S.; Harris, K. \& Larsen, L. (2001). Prevention and intervention of writing difficulties for students with learning disabilities. Learning Disabilities Research $\mathcal{E}$ Practice, Vol. 16, No. 2, pp. 74-84, ISSN 1540-5826.

Graham, S.; Harris, K.; McArthur, C. \& Fink, B. (2002). Primary grade teachers' theoretical orientations concerning writing instruction: Construct validation and a nationwide survey. Contemporary Educational Psychology, Vol. 27, pp. 147-166, ISSN 0361-476X.

Jiménez, J.; Ortiz, M.; Rodrigo, M.; Hernández, I.; Trabaue, M.; Estévez, A. \& Ramírez, G. (2003). Do the effects of computer-assisted practice differ for reading-disabled children with or without IQ-achievament discrepancy? Journal of Learning Disabilities, Vol. 36, pp 4-47, ISSN 0022-2194.

Nkhoma, P. (2002). What successful Black South African students consider as factors of their success. Educational Studies in Mathematics, Vol. 50, pp. 103-113, ISSN 1573-0816.

Pacheco, D. (2010). Opiniones, enfoque, acciones y autoeficacia del profesor y rendimiento del alumno en composición escrita. [Opinions, approach, actions and self-efficacy of teachers and student performance in written composition, 2007], Serie Tesis Doctorales. Universidad de León, ISBN 978-84-9773-515-5, León, España.

Pacheco, D.; García, J. \& Díez, C. (2007). La práctica de los profesores en la enseñanza de la composición escrita. [The practice of teachers in the teaching of written composition]. Dificultades del desarrollo: Evaluación e intervención, In J. N. García (Coord.), pp. 267-277, Pirámide, (Ed.), ISBN 978-84-368-2008-0, Madrid, Spain.

Pacheco. D.; García, J. \& Díez, M. (2009). Self-efficacy, approach, and teacher's practice in the writing teaching. European Journal of Psychology and Education, Vol. 2, No. 2, pp. 523, ISSN 1888-8992.

Parr, J. (1994). When pens are passé: Students reflect on written composition. Journal of Research on Computing in Education, Vol. 27, No. 2, pp. 221-231, ISSN 0735-6331.

Perez, S. (2001). Revising during writing in a second grade classroom. Educational Research Quartely, Vol. 25, No. 1, pp. 27-32, ISSN 0885-2006 I.

Persky, H.; Daane, M. \& Jin, Y. (2003). The Nation's Report Card: Writing 2002. Washington, DC: National Center for Education Statistics.

Rosino, M. (2009). La escritura en el proceso educativo. [Writing in the educational process]. Revista para la difusión del conocimiento educativo. RE.DI.CE, Vol. 2, pp. 1-20, ISSN 1989-2063 1.

Stokking, K.; Van der Schaaf, M.; Jaspers, J. \& Erkens, G. (2004). Teachers' assessment of students research skills. British Educational Research Journal, Vol. 30, No. 1, pp. 93116, ISSN 1873-9326.

Taylor, B.; Peterson, D.; Pearson, P. \& Rodríguez, M. (2002). Looking inside classrooms: Reflecting on the "how" as well as the "what" in effective reading instruction. The Reading Teacher, Vol. 56, No. 3, pp. 270-279, ISSN 0034-0561.

Troia, G. (2006). Writing instruction for students with learning disabilities. In: Handbook of Writing Research, Charles A. MacArthur, Steve Graham, Jill Fitzgerald, (Ed.), pp. 324-336, The Guilford Press, ISBN 1-59385-190-1, New York, United States of America. 
Troia, G. \& Maddox, M. (2004). Writing instruction in middle schools: special and general education teachers share their views and voice their concerns. Exceptionality, Vol. 12, No. 1, pp. 19-37, ISSN 0936-2835.

Valle, A.; Núñez, J.; Cabanach, R.; González, J.; Rodríguez, S.; Rosário, P.; Cerezo, R. \& Muñoz, M. (2008). Self-regulated profiles and academic achievement. Psicothema, Vol. 20, No. 4, pp. 724-731, ISSN 1132-9483.

Villalobos, J. (2007). La enseñanza de la escritura a nivel universitario: Fundamentos teóricos y actividades prácticas basados en la teoría sociocultural [Teaching writing at university level: Theoretical and practical activities based on sociocultural theory] Artículos arbitrados, Vol. 36, pp. 61-71. 


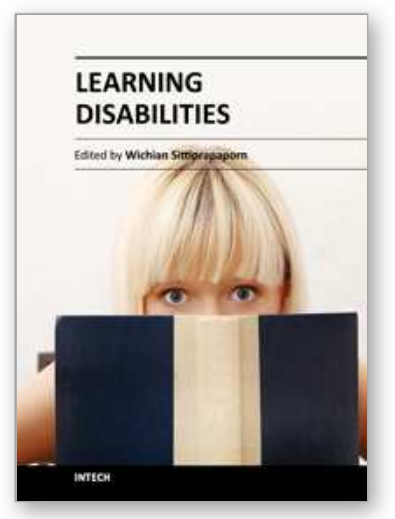

\author{
Learning Disabilities \\ Edited by Dr. Wichian Sittiprapaporn
}

ISBN 978-953-51-0269-4

Hard cover, 364 pages

Publisher InTech

Published online 14, March, 2012

Published in print edition March, 2012

Learning disability is a classification that includes several disorders in which a person has difficulty learning in a typical manner. Depending on the type and severity of the disability, interventions may be used to help the individual learn strategies that will foster future success. Some interventions can be quite simplistic, while others are intricate and complex. This book deserves a wide audience; it will be beneficial not only for teachers and parents struggling with attachment or behavior issues, but it will also benefit health care professionals and therapists working directly with special needs such as sensory integration dysfunction.

\title{
How to reference
}

In order to correctly reference this scholarly work, feel free to copy and paste the following:

Deilis Ivonne Pacheco Sanz and Jesús-Nicasio García-Sánchez (2012). The Quality of Teaching Determines Students' Achievement in Writing, Learning Disabilities, Dr. Wichian Sittiprapaporn (Ed.), ISBN: 978-953-510269-4, InTech, Available from: http://www.intechopen.com/books/learning-disabilities/the-quality-of-teachingdetermines-students-achievement-in-writing

\section{INTECH}

open science / open minds

\section{InTech Europe}

University Campus STeP Ri

Slavka Krautzeka 83/A

51000 Rijeka, Croatia

Phone: +385 (51) 770447

Fax: +385 (51) 686166

www.intechopen.com

\section{InTech China}

Unit 405, Office Block, Hotel Equatorial Shanghai

No.65, Yan An Road (West), Shanghai, 200040, China

中国上海市延安西路65号上海国际贵都大饭店办公楼405单元

Phone: +86-21-62489820

Fax: +86-21-62489821 
(C) 2012 The Author(s). Licensee IntechOpen. This is an open access article distributed under the terms of the Creative Commons Attribution 3.0 License, which permits unrestricted use, distribution, and reproduction in any medium, provided the original work is properly cited. 